\title{
Taxonomy and biodiversity of the genus Oscillatoria Vauch. ex Gom. (Cyanoprokaryota: Oscillatoriales) with ecological notes from Hooghly in West Bengal, India
}

\section{Nilu Halder}

Department of Botany, Raja Peary Mohan College, Uttarpara-712258, Hooghly, West Bengal, India. Email: niluhalder1@gmail.com.

\begin{abstract}
Research articles in the reference list regarding investigation or exploration of Oscillatoriales exhibited that taxonomic study of freshwater blue-green algae has been a subject of interest of research workers and professional scientists for more than one century in India. Oscillatoria Vauch. ex Gom. (Cyanoprokaryota: Oscillatoriales) is a dominant and ubiquitous blue-green alga in Hooghly District of West Bengal, India. Its thallus is consists of unsheathed trichome and contains more than 20 cells in a trichome. The recent study was dealt with the taxonomic enumeration of five species of the genus (O. princeps, O. curviceps, O. sancta, O. limosa, and O.jenensis) which were collected from different freshwater aquatic ecosystems of this district and they were described with ecological data, geographical distributions and colored microphotographs. Here, the relationships between the water chemistry and their occurrences had been also discussed. The analysis of important physico-chemical properties of water revealed that species of Oscillatoria prefer to grow in those water bodies prevailing alkaline $\mathrm{pH}$, sufficient to meet the essential nutrients and contain hard and polluted water.
\end{abstract}

Keywords: Taxonomy; Oscillatoria; West Bengal; India.
Received

December 03, 2016

Accepted

June 24, 2017

Released

June 30, 2017

Open Acess Full Text Article

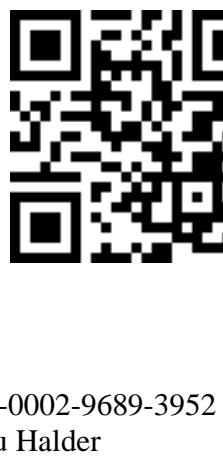

\section{Introduction}

Indeed, blue-green algae (Cyanoprokaryota) are one of the most successful and primitive microbes or plant groups in our planet since the origin of life. They resemble with eukaryotic algae as well as prokaryotic bacteria because they share some common features of both the groups and included in the Kingdom Monera by Whittaker (1969). Blue-green algae are basically aerobic photoautotrophs, although they may be able to live anaerobically. Only warm temperature, water, $\mathrm{CO}_{2}$, inorganic substances like nitrogen and phosphorus and sunlight are sufficient for abundant growth, reproduction and to complete their life cycles (Kasthuri et al., 2016). They are considered the first organism to release elemental oxygen $\left(\mathrm{O}_{2}\right)$ into the primitive atmosphere (Gupta et al., 2006) and primary colonizer in bare areas of rock and soil (Issa et al., 2014). Ultraviolet ray absorbing sheath and a combination of green and unique blue pigments, probably increase their fitness in the exposed land environment (Mur et al., 1999). The morphological simplicity and occurrence of polymorphisms (variations) in nature sometimes make this plant group difficulty (Roger and Reddy, 1984) for identifications 
under light microscopy. They show variations in thallus organizations (unicellular, colonial to filamentous) and measurement of vegetative as well as reproductive structures due to response of changes in environmental conditions. They can thrive or adapt in adverse climatic conditions of any ecological ecosystems, being photosynthetic prokaryotes (Seal et al., 2015; Halder, 2016a) and possessing simple thallus structures. Oscillatoria Vauch. ex Gom. is a very common and dominant blue-green algal genus of Cyanophyceae and it has been found to occur in almost all the types of freshwater habitats like ponds, moats, irrigation channels, water logged rice fields, lakes, rivers, canals or in any polluted water bodies of urban areas throughout the world. It is a highly pollution tolerant blue-green alga (Patrick, 1965). Occasionally, they are noticed on water surface as dark blue or black algal mass/scum and their colonies may buoyant as containing of air bubbles. Therefore, they can blow by gentle wind from one place to another in aquatic bodies. Globally, there are 304 species of this genus which are taxonomically accepted in algae database (Guiry and Guiry, 2016) and till date ca. 128 species of this genus have been reported from different places of India (Tiwari et al., 2007). The species of Oscillatoria grow in monsoon. In winter, they are mostly observed in water channels, sewage water while in summer their distribution observed only in perennial drains and few water reservoirs (Kesarwani et al., 2015). The genus is characterized by these common features, i) thallus is predominantly blue-green or may be blackish, grayish, olive-green; consists of trichome and sometimes forms macroscopic mat, rarely solitary or in small groups, ii) trichomes flat, simple, uniseriate, usually fine, straight or slightly waved, cylindrical and show gliding motion under light, iii) constricted or not constricted at cross walls, attenuated or not attenuated to the ends, iv) sheath absent or thin, colorless only in suboptimal (extreme) conditions, v) cells always shorter than wide, without aerotopes but with fine granulation (sometimes prominent at the cross walls), vi) apical or end cells rounded, hemispherical, sometimes capitate or with narrow calyptras, vii) vegetative reproduction occurs by means of cell division that is perpendicular to the long axis of a trichome or formation of hormogonia or trichome disintegration, e viii) heterocyst is lacking in trichomes (Komárek and Anagnostidis, 2005).

Seasonal variations of water properties (Halder, 2016b) and tropical climatic/environmental conditions (Halder and Sinha, 2013a,b; Halder, 2015a) play important roles in the distribution of cyanobacterial algae in natural water bodies. Few ecological parameters like temperature, light intensity and dissolved solids have a great impact on growth stage and occurrence of blue-green algae (Kullberg, 1977). Maximum growth is attained by most blue-green algae in summer i.e. at higher temperature in comparison to green algae and diatoms (Robarts and Zohary, 1987; Mur et al., 1999). A low ratio between nitrogen and phosphorus compounds in water may favor the development of this algal group (Smith, 1983; Harris et al., 2016).

The alga has a considerable importance to human beings. Ecologically, it plays crucial role in the treatment of sewage effluents, bioremediations and nutrient recycling. Besides these, the alga also showed in vitro antimicrobial (Prabakaran, 2011) and antibacterial effects against the pathogenic microbes (Abd ElAty et al., 2014) due to having antimicrobial substances like terpenes, phenols and phenolic compounds in their cells like other algae (Halder and Sinha, 2014a; Sinha et al., 2015; Halder, 2015b). Thus, it may be utilized as a promising source to manufacture antibacterial drugs in pharmaceutical industry in future. It should be mentioned that recently, different species of Cyanobacteria have been using for extraction of cyanobacterial restriction endonucleases that generally recognize palindromic sequences in DNA, cleave within or near their recognition sequences and produce DNA-fragments of different lengths. Among them, AvaI is well known restriction enzyme from Anabeaena 
variabilis. Saravanan et al. (2003) purified (through column chromatography) and characterized a new type II restriction endonuclease, OfoI from a nonheterocystous cyanobacterium Oscillatoria foreaui and the recognition sequence has been detected with the help of primer extension analysis. This enzyme recognizes and cleaves the palindromic hexanucleotide sequence 5'-C $\downarrow$ YCGRG-3' in DNA and producing 5'-protruding ends of defined sizes.

There are many detailed taxonomic floristic reports and information on the genus from India including those of Kamat (1963), Anand (1989), Tiwari (1975), Mahajan and Patel (1989), Kumawat and Jawale (2006), Adhikary (2007), Goyal et al. (2008), Deka and Sarma (2011), Kesarwani et al. (2015) and many other published scientific papers. Abroad India, the commendable algological work of Komarek and Anagnostidis (2005) and McGregor (2007) may be mentionable regarding on the Order Oscillatoriales. Some previous workers who contributed on the taxonomy of the genus from this state (West Bengal) may be cited Martens (1871), Prain (1905), Biswas (1926, 1932), Pal and Santra (1985, 1987), Santra et al. (1988), Sen and Gupta (1987, 1998), Sen and Naskar (2003), Naskar et al. (2008), Chakraborty et al. (2010), Sen Sarkar et al. (2013). The main objective of this study was to investigate the biodiversity of the genus Oscillatoria Vauch. ex Gom. from Hooghly, West Bengal, India.

\section{Materials and Methods}

\section{Sample collection}

Algal samples were collected from freshwater bodies located in five different sites viz. Khanyan (site-1), Serampore (site-2), Chinsurah (site-3), Chandannagar (site-4), and Mogra (site-5) of Hooghly district $\left(20^{\circ} 30^{\prime} 32^{\prime \prime}-23^{\circ} 01^{\prime} 20^{\prime \prime} \mathrm{N}\right.$ and $87^{\circ} 30^{\prime} 20^{\prime \prime}-80^{\circ} 30^{\prime} 15^{\prime \prime} \mathrm{E}$ ) in West Bengal, India. The map of Hooghly district had been already provided earlier in few research articles (Halder and Sinha, 2014b; Sinha and Halder, 2014; Halder, 2015c).

\section{Microscopy}

Microscopic study of the five species of Oscillatoria Vauch. ex Gom. was made by examining them under Olympus microscope (Model-CH20i). Microphotographs were taken using Canon Power Shot A480 camera. The samples were preserved in $4 \%$ formalin and the voucher specimens were deposited in the Departmental Herbarium of R. P. M. College, Uttarpara, Hooghly, West Bengal.

\section{Identification}

This was done with the aid of relevant monographs, manuals and recent literatures (Gomont, 1892; Geitler, 1932; Desikachary, 1959; Prescott, 1962; Prasad and Srivastava, 1992; Gupta, 2005; Jain, 2015; Kesarwani et al., 2015).

\section{Water analysis}

The temperature $\left({ }^{\circ} \mathrm{C}\right)$ and $\mathrm{pH}$ of the freshwater were recorded at the sites with the help of mercury thermometers and portable $\mathrm{pH}$ meter. The other limnological parameters such as nitrate-nitrogen $\left(\mathrm{NO}_{3}-\mathrm{N}\right)$, phosphate $\left(\mathrm{PO}_{4}{ }^{3-}\right)$, biological oxygen demand (BOD), chemical oxygen demand (COD) and total hardness (TH) of water were estimated following the standard method (APHA, 2005).

\section{Results}

On the basis of traditional morphological features a total number of five species of the above said genus had been identified and described in the present work. All these species had been collected from freshwaters. Among them, two species (O. princeps and $O$. limosa) were most common regarding their abundances in this locality. 


\section{Key to the species}

1. Trichomes more than $20 \mu \mathrm{m}$ in diameter .......... O. princeps

1 '. Trichomes less than $20 \mu \mathrm{m}$ in diameter ..................... 2

2. Trichomes hooked at the apex ........................ O. curviceps

2'. Trichomes straight or slight bent .............................. 3

3. Trichomes cylindrical with constrictions, apex attenuated and capitate with a calyptras O. sancta

3’. Trichomes not so 4

4. Trichomes straight, not attenuated and apical cell rounded or often convex O. limosa

4'. Trichomes broader (above $17.0 \mu \mathrm{m}$ ), apex widely rounded or sometimes conical-rounded O. jenensis

1. Oscillatoria sancta (Kütz.) Gom. in Ann. Sci. Nat. Bot., Ser. 7, 16: 209, 1892; Desikachary, Cyanophyta 203, pl. 42, fig. 10, 1959; Prasad and Srivastava, Fr. Water Al. Fl. Andaman and Nicobar Islands v. I. p. 70, pl. 9, fig. 8, 1992; Kesarwani et al., in Phykos 45 (1): 21, 23-24, pl. 1, fig. 18; pl. 3, fig. 43; pl. 4, fig. 44, 2015 (Figure 1. A).

Description: Thallus brownish or bluish-green and shining; trichome single, straight, elongated, one end briefly attenuated; cells 13.0-15.5 $\mu \mathrm{m}$ broad and shorter than broad; 4.0-5.0 $\mu \mathrm{m}$ long, distinctly constricted at cross walls and granulated; cell contents light blue-green, homogeneous; apical cell hemispherical and attenuated; cell wall thick.

Habitat: Free floating in a pond water at Khanyan (23 $04^{\prime} \mathrm{N}, 88^{\circ} 32^{\prime} \mathrm{E}$ ).

Date of collection: 07.06.2013; Collection number: NH 1280.

Indian distribution: Jammu and Kashmir, Himachal Pradesh, Uttarakhand, Punjab, Haryana, Delhi, Rajasthan, Uttar Pradesh, Madhya Pradesh, Maharashtra, Gujarat, Chhattisgarh, Andhra Pradesh, Karnataka, Kerala, Tamil Nadu, Andaman and Nicobar Islands, Bihar, Orissa, Arunachal Pradesh, Meghalaya, Tripura, Assam, Sikkim (Gupta, 2012); West Bengal (Banerji, 1938; Kachroo, 1959; Sen and Gupta, 1998, Sikdar and Keshri, 2014).
Other countries: It was reported from Britain (Whitton et al., 2003) in Europe; Arkansas (Smith, 2010) in North America; Argentina (Rodriguez et al., 2006) in South America; Cuba (Comas Gonzalez and Moreira González, 2010) in Caribbean Islands; Mauritius (Silva et al., 1996) in Africa; Queensland (Day et al., 1995) in Australia (Giury and Guiry, 2016).

Remarks: Trichome constricted at cross wall, apical cell somewhat capitates or sub-capitates, with a calyptras; cells 1113-(20) $\mu \mathrm{m}$ broad, 4-5 $\mu \mathrm{m}$ long; slightly constricted at the cross walls with conspicuous granules; cell contents coarsely granular-all these species distinguishing characters were observed in this specimen and confirmed that the present species is Oscillatoria sancta.

2. O. princeps Vauch. ex Gom.; Vaucher in Hist. Conf. 190, pl. 15, fig. 2, 1803; Gomont in Ann. Sci. Nat. Bot., Ser. 7, 16: 201, 206, pl. 6, fig. 9, 1892; Geitler, Kryptogamen-Fl. 947, figs. 598a, 601c-g, 1932; Desikachary, Cyanophyta 210, pl. 37, figs. 1, 10-11, 13-14, 1959; Prescott, Al. Western Great Lakes 489, pl. 110, fig, 1, 1962; Prasad and Srivastava, Fr. Water Al. Fl. Andaman and Nicobar Islands v. I. p. 67, pl. 8, fig. 8 \& 10, 1992; Kesarwani et al., in J. Indian Bot. Soc. 94 (1 \& 2): 4243, 2015 (Figure 1. B-C). 
Description: Thallus blackish bluegreen or dark blue-green; trichome solitary, floating, mostly straight or slightly curved at apex, rigid and longer; 25.0-28.0 $\mu \mathrm{m}$ broad and cells $1 / 5$ to $1 / 7$ times as long as broad or more shorter, 3.0-4.0 $\mu \mathrm{m}$ long, cell content olive blue-green, homogeneous, without gas vacuoles, finely granulated, terminal end slightly attenuated, \pm bent, truncate with wavy margins and cell wall thick.

Habitat: Free floating in a reservoir water at Serampore $\left(22^{\circ} 76^{\prime} \mathrm{N}\right.$, $88^{\circ} 34^{\prime}$ E).

Date of collection: 11.06.2013; Collection number: NH 1283.

Indian distribution: Jammu and Kashmir, Himachal Pradesh, Uttarakhand, Punjab, Haryana, Delhi, Rajasthan, Uttar Pradesh, Madhya Pradesh, Maharashtra, Gujarat, Chhattisgarh, Andhra Pradesh, Karnataka, Kerala, Tamil Nadu, Andaman and Nicobar Islands, Bihar, Orissa, Arunachal Pradesh, Manipur, Meghalaya, Nagaland, Tripura, Assam, Sikkim (Gupta, 2012); West Bengal (Biswas, 1925, 1927, 1949; Banerji, 1938; Kachroo, 1959; Sinha and Mukherjee, 1975; Santra et al., 1988; Sen and Gupta, 1998; Sen and Naskar, 2003; Naskar et al., 2008; Chakraborty et al. 2010; Sikdar and Keshri, 2014).

Other countries: It was recorded from Britain (Whitton et al., 2003), Germany (Täuscher, 2015) in Europe; Arkansas (Smith, 2010) in North America; Argentina (Tell, 1985) in South America; Cuba (Comas Gonzalez and Moreira González, 2010) in Caribbean Islands; Mozambique (Silva et al., 1996) in Africa; New South Wales (Day et al., 1995) in Australia (Guiry and Guiry, 2016).

Remarks: Trichome is much broader (above $20 \mu \mathrm{m}$ ) than other species and slightly or briefly attenuated at the apices and slight bent; cells 25-55-(80) $\mu \mathrm{m}$ broad, 3-8.7 $\mu \mathrm{m}$ long and not constricted at the cross walls and not granulated but cell content is granular. These important characteristics resemble the present specimen as $O$. princeps.

3. Oscillatoria limosa (Dillw.) C. Ag. in Disp. Alg. Suec. 4: 35, 1812 as
Conferva limosa Dillw.; Geitler, Kryptogamen-Flora 944, fig. 598d, 1932; Desikachary, Cyanophyta 206, pl. 42, fig.11, 1959; Prescott, Al. Western Great Lakes 489, pl. 109, fig. 17, 1962; Prasad and Srivastava, Fr. Water Al. Fl. Andaman and Nicobar Islands v. I. 65, pl. 9, figs. 4, 14, 1992; Gupta, Al. Fl. Dehradun District Uttaranchal 238, pl. 62, fig 9, 2005 (Figure 1. D-E).

Synonymous: Oscillatoria limosa C. Ag. ex Gom.

Description: Thallus dark bluegreen or light yellow-green; trichome straight, solitary or form mats; trichome 13.0-14.5 $\mu \mathrm{m}$ broad and 3.0-5.0 $\mu \mathrm{m}$ long; not attenuated and without constriction at the cross-walls; apical cell often convex with thickened outer cell wall, flat-rounded or obtuse-rounded, no calyptras; cell content olive-green, finely granulated, granules uniformly distributed, rarely with thin and colorless sheath.

Habitat: Free floating in water logged rice field at Chinsurah $\left(22^{\circ} 88^{\prime} \mathrm{N}\right.$, $88^{\circ} 39^{\prime} \mathrm{E}$ ).

Date of collection: 03.09.2013; Collection number: NH 1314.

Indian distribution: Jammu and Kashmir, Himachal Pradesh, Uttarakhand, Punjab, Haryana, Rajasthan, Uttar Pradesh, Madhya Pradesh, Maharashtra, Gujarat, Chhattisgarh, Andhra Pradesh, Karnataka, Kerala, Tamil Nadu, Bihar, Orissa, Manipur, Meghalaya, Nagaland, Assam, (Gupta, 2012); West Bengal (Martens, 1871; Prain, 1905; Biswas, 1926; Kachroo, 1959; Sen and Gupta, 1987, 1998; Santra et al., 1988; Sen and Naskar, 2003; Naskar et al., 2008; Chakraborty et al. 2010, Sen Sarkar et al., 2013; Sikdar and Keshri, 2014).

Other countries: Britain (Whitton et al., 2003), Germany (Täuscher, 2015), Italy (Di Pippo et al., 2014) in Europe; Arkansas (Smith, 2010), Mexico (FigueroaTorres et al., 2015) in North America; Argentina (Tell, 1985), Brazil (Bicudo and Martau, 1974) in South America; Cuba (Comas Gonzalez and Moreira González, 2010) in Caribbean Islands; Mozambique (Silva et al., 1996), Egypt (Nassar and Khairy, 2014) in Africa; New South Wales 
and Queensland (Day et al., 1995) in Australia.

Remarks: Trichome straight; cells 13-18-(20) $\mu \mathrm{m}$ in diameter, 3.7-5.0 $\mu \mathrm{m}$ long which are not constricted at the cross walls, cell content usually granular-these features come close to the species $O$. limosa.

4. Oscillatoria curviceps C . Ag. ex Gom. in Syst. Alg. 68, 1824; Desikachary, Cyanophyta 209, pl. 38, fig. 2; pl. 39, figs. 9-10 and pl. 42, fig. 10, 1959; Prasad and Srivastava, Fr. Water Al. Fl. Andaman and Nicobar Islands v. I. 62, pl. 9, fig. 12, 1992; Jain in J. Exp. Biol. Agric. Sci. 3(2):133, pl.1, fig. 4, 2015 (Figure 1. F).

Description: Trichomes free floating, blue-green, forming an expanded mass; cells 11.0-13.0 $\mu \mathrm{m}$ broad, cells $1 / 3-$ $1 / 6$ as long as broad, 3.0-5.0 $\mu \mathrm{m}$ long, often granulate at cross walls, trichomes straight or terminally curved; end cell broadly rounded often with lightly thickened outer membrane, not capitates and not constricted at cross walls.

Habitat: Drain water at Chandannagar $\left(22^{\circ} 86^{\prime} \mathrm{N}, 88^{\circ} 36^{\prime} \mathrm{E}\right)$.

Date of collection: 18.08.2013; Collection number: NH 1305.

Indian distribution: Jammu and Kashmir, Himachal Pradesh, Uttarakhand, Punjab, Haryana, Rajasthan, Uttar Pradesh, Madhya Pradesh, Maharashtra, Gujarat, Chhattisgarh, Andhra Pradesh, Karnataka, Kerala, Tamil Nadu, Andaman and Nicobar Islands, Bihar, Orissa, Assam (Gupta, 2012); West Bengal (Santra et al., 1988; Sen and Naskar, 2003; Naskar et al., 2008).

Other countries: Germany (Täuscher, 2015), Romania (Caraus, 2012) in Europe; Arkansas (Smith, 2010) in North America; Argentina (Tell, 1985) in South America; Mozambique (Silva et al., 1996), Egypt (Nassar and Khairy, 2014) in Africa; New South Wales (Day et al., 1995) in Australia; New Zealand (Broady and Merican, 2012), Singapore (Pham et al., 2011); Nepal (Rai et al., 2010), Bangladesh (Silva et al., 1996) in Asia.
Remarks: Trichome hook shaped, mostly forming an expanded blue-green mass, apical cell broadly rounded, not capitates. Cells 10-14-(17) $\mu \mathrm{m}$ in diameter, 3.0-5.0 $\mu \mathrm{m}$ long; not constricted at the cross walls, which may be granulate. The present specimen contains all these distinguishing characters and therefore, confirmed that this species is $O$. curviceps.

5. Oscillatoria jenensis G. Schmid in Jahrb. Wiss. Bot. 60: 572, figs. 1-2, 1921; Kamat in phykos 13: 29, 1974; Kesarwani et al., in Phykos 45(1): 27, pl. 2, fig. 27, 2015 (Figure 1. G-H).

Description: Trichome flat, bluegreen or yellow-green, solitary, straight but with short attenuation at end; terminal cell often pale olive-green, sometimes capitate or with narrow calyptras or with two thornlike structures, widely rounded or sometimes conical-rounded, often asymmetrical; 17.5-20.0 $\mu \mathrm{m}$ wide, 2.0-4.0 $\mu \mathrm{m}$ long, constricted or not constricted at the cross walls; cells without aerotopes but with prominent granules; reproduction by trichome disintegration.

Habitat: Free floating in moat water at Mogra (22 $\left.97^{\prime} \mathrm{N}, 88^{\circ} 37^{\prime} \mathrm{E}\right)$.

Date of collection: 14.04.2013; Collection number: NH 1265.

Indian distribution: Maharashtra (Kamat, 1974); Uttar Pradesh (Kesarwani et al., 2015).

Other countries: Romania (Caraus, 2012), Spain (Alvarez-Cobelas and Gallardo, 1988) in Europe; Cuba (Comas González, 2008) in Caribbean Islands; Mozambique (Silva et al., 1996) in Africa; Queensland (Bostock and Holland, 2010) in Australia; Pakistan (Lashari et al., 2009) in Asia.

Remaks: The present species is closely related and looks like $O$. princeps var. pseudolimosa Ghose but cellular measurements and other morphological features coincided with the type species of $O$. jenensis. It appears to be new report from this state (West Bengal). 

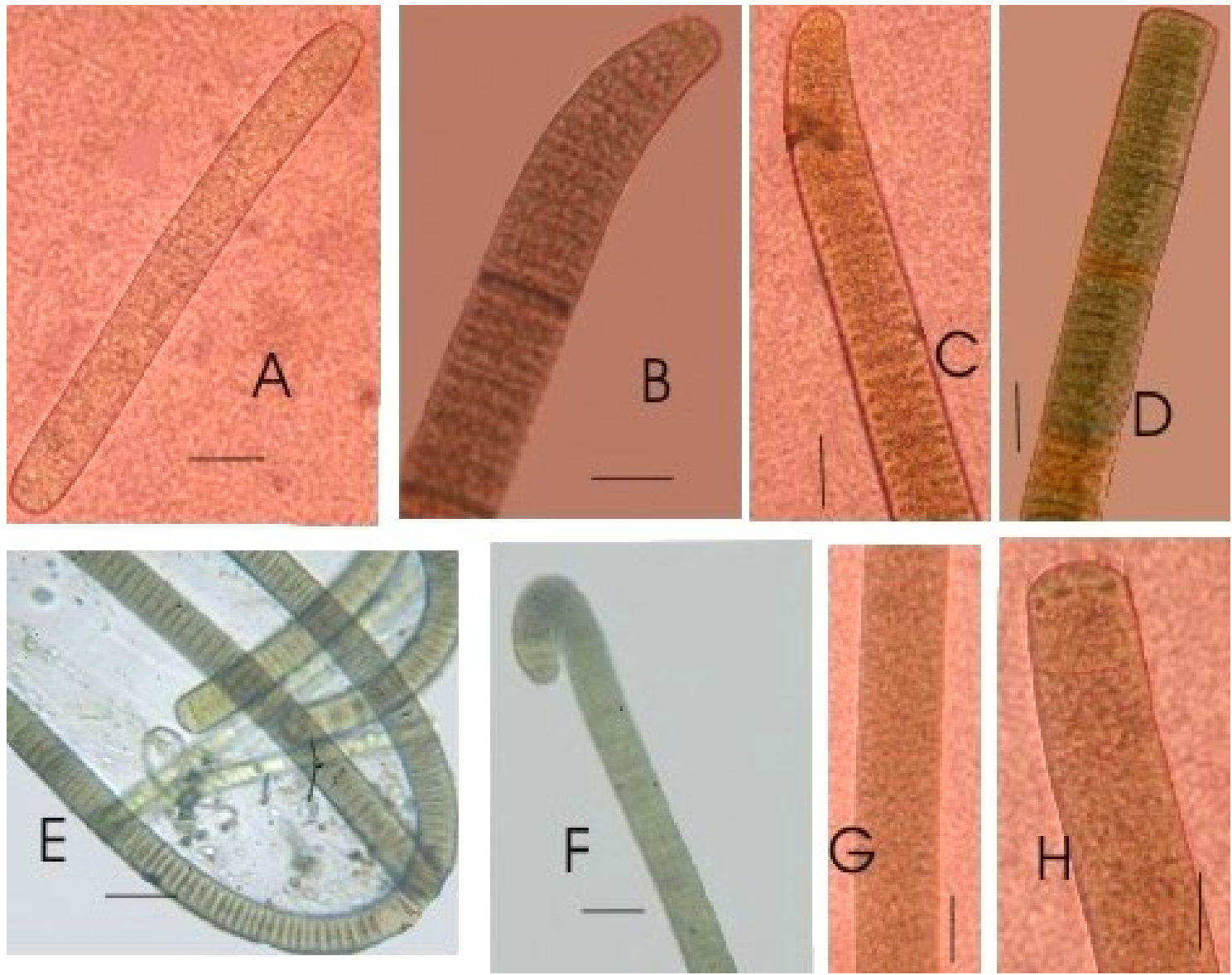

Figure 1. A. Oscillatoria sancta, B-C. O. princeps, D-E. O. limosa, F. O. curviceps, G-H. O. jenensis. Bar $=15 \mu \mathrm{m}$.

\section{Discussion}

Algae generally grow in water bodies and constitute the major group of primary producers (Halder, 2015d) although, global biodiversity and natural habitats of algae are being lost at an unprecedented rate as a result of anthropogenic human activities. Therefore, measurements must be taken now to combat this trend and also for their conservations. A key goal of taxonomic investigation is the exploration of biodiversity (Sinha et al., 2016) of available or existing species/genera from a particular geographical area, locality or region or to know the present status of specific species or genera/genus from those places. In this study, taxonomic results showed that the genus is cosmopolitan in distribution through out the district and showed a great diversity in respect of their species richness. From floristic survey in this region, a total number of five species had been documented and described. These are $O$. sancta (Kütz.) Gom., O. princeps Vauch. ex Gom., O. limosa (Dillw.) C. Ag., O. curviceps C. Ag. ex Gom. and O. jenensis G. Schmid. Among them, O. princeps and $O$. limosa were continuous in distribution (dominant) among the four seasons while $O$. sancta was found throughout the year except winter and $O$. curviceps was less frequent but $O$. jenensis was rare in phenology from this area and represented only in summer (Table 1). 
Table 1. Showing species phenology and abundances.

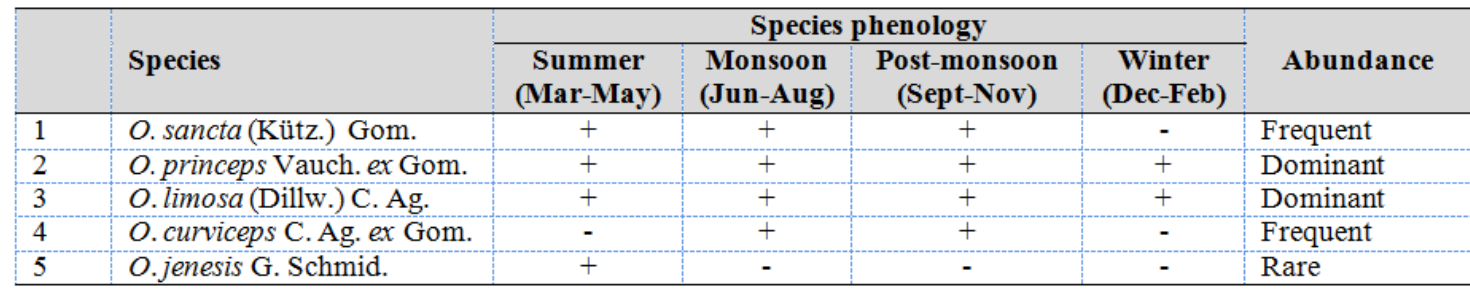

The symbol + represented present while - represented absent of species.

They were all found only in fresh water habitats particularly in lentic water bodies. In the taxonomy of blue-green algae, measurement of trichome and cell size play an important role at the species level identifications. According to Roger and Reddy (1984), in nature numerous morphological variations or deviations which are not genetically stable exist within specific algal taxa. This opinion is found to be true in this study because Oscillatoria exhibited so. Here, morphological characters like colour, measurement of width of trichome, nature of apical cell, constriction and granulation have been taken as the distinguishing features for segregating or delimiting the species of this taxon.

The occurrence and diversity of blue-green algae are directly affected by physical and chemical limnological factors of water bodies. The result of water analysis of few limnological parameters has been added in this article. Temperature effects on blooming and dominance of blue-green algae (Robarts and Zohary, 1987). They require warm temperature for their accelerated growth which was also observed in the present work. Species of Oscillatoria attain growth in a range between $30.5{ }^{\circ} \mathrm{C}$ to $33.5^{\circ} \mathrm{C}$. Thus, the result is inconformity with earlier findings of (Konopka and Brock, 1978). $\mathrm{pH}$ as a determining factor of distribution of the genus in water bodies ranged from 7.7 to 8.0. In all the study sites, $\mathrm{pH}$ of water was found within the alkaline range like the previous observations (Halder, 2015e; 2016c,d). A close relationship between alkaline water and occurrence of cyanobacteria has been also stated by several workers (Verma and Mohanty, 1995; Nayak and Prasanna, 2007). During the present investigation, the amount of dissolved oxygen (DO) ranged between 5.8 to $6.6 \mathrm{mg} . \mathrm{L}^{-1}$. It showed that studied aquatic bodies were still with sufficient oxygen levels and not highly polluted. BOD was observed from 3.2-4.6 mg. $\mathrm{L}^{-1}$ which suggested that water was not becoming anaerobic. For assessing organic pollution, COD was measured and noticed in a range from 40.0-90.0 mg. $\mathrm{L}^{-1}$. The analysis of both BOD and COD values indicated that pollution load was present in all the studied aquatic bodies. Most of the ecological studies revealed that if, nutrients levels increase rapidly cyanobacterial bloom occurs and can result an entropic condition in aquatic environments. The primary nutrients like nitrate-nitrogen and phosphates have a great influence on optimal growth, productivity of algae and they are also correlated to each other. In this study, species of Oscillatoria were found dominant even in availability of lower nutrient contents in water bodies. Nitrate-nitrogen and phosphates had been estimated from 0.10-0.22 mg. $\mathrm{L}^{-1}$ and $0.20-$ 0.36 mg. $\mathrm{L}^{-1}$, respectively. Lower concentration of the nutrient parameters was also measured in another study by the author (Halder, 2016e). Total hardness is an important factor for algal occurrence. It was recorded from 164.0-310.0 mg. $\mathrm{L}^{-1}$ concentrations. Thus, the result exhibited that Oscillatoria tends to tolerate a wide range of total hardness values. Therefore, 
from the analysis of water parameters it could be reported that blooming of Oscillatoria preferably noticed in alkaline $\mathrm{pH}$, hard water and polluted aquatic bodies.
Besides these, all those above parameters had a great impact on their phenology and growth.

Table 2. Physico-chemical characteristics of waters in the five collection sites in Hooghly.

\begin{tabular}{|c|c|c|c|c|c|c|}
\hline & $\begin{array}{l}\text { Physico- } \\
\text { chemical } \\
\text { parameter }\end{array}$ & $\begin{array}{c}\text { Khanyan } \\
\text { (Site-1) } \\
\text { Results }\end{array}$ & $\begin{array}{c}\text { Serampore } \\
\text { (Site-2) } \\
\text { Results }\end{array}$ & $\begin{array}{c}\text { Chinsurah } \\
\text { (Site-3) } \\
\text { Results }\end{array}$ & $\begin{array}{l}\text { Chandannagar } \\
\text { (Site-4) Results }\end{array}$ & $\begin{array}{l}\text { Mogra } \\
\text { (Site-5) } \\
\text { Results }\end{array}$ \\
\hline 1 & Temp. $\left({ }^{\circ} \mathrm{C}\right)$ & $32.00 \pm 0.28$ & $32.50 \pm 0.28$ & $30.50 \pm 0.28$ & $31.50 \pm 0.28$ & $33.50 \pm 0.28$ \\
\hline 2 & $\mathrm{pH}$ & $7.90 \pm 0.05$ & $7.80 \pm 0.05$ & $8.00 \pm 0.04$ & $7.80 \pm 0.05$ & $7.70 \pm 0.05$ \\
\hline 3 & DO (mg. $\left.\mathrm{L}^{-1}\right)$ & $6.00 \pm 0.11$ & $5.80 \pm 0.12$ & $6.40 \pm 0.13$ & $6.20 \pm 0.12$ & $6.60 \pm 0.11$ \\
\hline 4 & BOD (mg.L $\left.L^{-1}\right)$ & $4.40 \pm 0.12$ & $4.60 \pm 0.11$ & $3.60 \pm 0.11$ & $4.20 \pm 0.13$ & $3.20 \pm 0.12$ \\
\hline 5 & COD (mg.L-1) & $80.00 \pm 5.70$ & $90.00 \pm 5.70$ & $50.00 \pm 5.70$ & $70.00 \pm 5.70$ & $40.00 \pm 5.70$ \\
\hline 6 & $\mathrm{NO}_{3}-\mathrm{N}\left(\mathrm{mg} \cdot \mathrm{L}^{-1}\right)$ & $0.20 \pm 0.05$ & $0.22 \pm 0.05$ & $0.12 \pm 0.06$ & $0.15 \pm 0.05$ & $0.10 \pm 0.05$ \\
\hline 7 & $\mathrm{PO}_{4}^{3-}\left(\mathrm{mg} \cdot \mathrm{L}^{-1}\right)$ & $0.34 \pm 0.06$ & $0.36 \pm 0.05$ & $0.22 \pm 0.07$ & $0.24 \pm 0.05$ & $0.20 \pm 0.06$ \\
\hline 8 & TH (mg. $\left.\mathrm{L}^{-1}\right)$ & $252.0 \pm 5.70$ & $310.0 \pm 2.80$ & $164.0 \pm 5.70$ & $218.0 \pm 2.60$ & $184.0 \pm 5.70$ \\
\hline
\end{tabular}

Values are Mean \pm SEM; Temp. $=$ Temperature, $\mathrm{DO}=$ Dissolved oxygen, $\mathrm{BOD}=$ Biological oxygen demand, $\mathrm{COD}=$ Chemical oxygen demand, $\mathrm{NO}_{3}-\mathrm{N}=$ Nitrate-nitrogen, $\mathrm{PO}_{4}{ }^{3-}=$ Phosphate, $\mathrm{TH}=$ Total hardness.

\section{Conclusion}

Morpho-taxonomic study will be helpful for routine identification, to know biodiversity and geographical occurrences of different species of the genus. Besides these, the genus is very common and abundantly found in a wide variety of habitats. Sometimes, it forms a thick bluegreen or slight blackish mass in stagnant water bodies. It can be recognized under compound microscope by its unsheathed trichome. Species of Oscillatoria grow rapidly if, water is found warmer, alkaline, nutrient rich, hard and polluted. In future, these cyanobacterial species can be used for bioremediations, nutrient recycling and careful screening methods to isolate new restriction enzymes.

\section{Conflict of interest statement}

Author declare that they have no conflict of interests.

\section{References}

Abd El-Aty, A. M.; Mohamed, A. A.; Samhan, F. In vitro antioxidant and antibacterial activities of two fresh water cyanobacterial species, Oscillatoria agardhii and Anabaena sphaerica. J. App. Pharm. Sci., v. 4, p. 69-75, 2014.

Adhikary, S. P. Freshwater algae of Eastern and North-Eastern region of India. Seminar Cum. Workshop on Taxonomy of Freshwater Algae and Their Utilization. Orissa: Utkal Univ., Bhubaneswar, 2007. p. 1-22.

Alvarez-Cobelas, M.; Gallardo, T. Catálogo de las algas continentales españolas V. Cyanophyceae Schaffner, 1909. Acta Bot. Malacit., v. 13, p. 53-76, 1988.

Anand, N. Hand book of blue-green algae. India: Dehradun, Bishen Singh Mahendra Pal Singh, 1989. p. 1-79.

APHA - American Public Health Association. Standard method for the examination of water and waste waters. 21 ed. Washington, DC: APHA, AWWA, WEF, 2005.

Banerji, J. Studies of Myxophyceae of lower Bengal, II. A few Hormogonales. J. Depart. Sci. Calcutta Univ., v. 1, p. 95-109, 1938.

Bicudo, C. E. M.; Martau, L. Catálago das algas de águas continentais do Estado do Rio Grande do Sul, Brazil, 2. Iheringia, Sér. Bot., v. 19, p. 31-48, 1974.

Biswas, K. Flora of the Salt Lake, Calcutta. J. Depart. Sci. Calcutta Univ., v. 8, p. 1-47, 1926. 
Biswas, K. Notes on the organisms in the filtered water of Calcutta. J. Proc. Asiatic Soc. Beng., v. 21, p. 533-539, 1932.

Bostock, P. D.; Holland, A. E. Census of the Queensland Flora. Brisbane: Queensland Herbarium Biodiversity and Ecosystem Sciences, Depart. Environm. Resource Mgmt., 2010.

Broady, P. A.; Merican, F. Phylum Cyanobacteria: blue-green bacteria, blue-green algae. In: Gordon, D. P. (ed.). New Zealand inventory of biodiversity. Vol. Three. Kingdoms Bacteria, Protozoa, Chromista, Plantae, Fungi. Christchurch: Canterbury Univ. Press, 2012. p. 50-69.

Caraus, I. Algae of Romania. A distributional checklist of actual algae. vers. 2. 3. rev. Bacau: Univ. of Bacau, 2012.

Chakraborty, T.; Mukhopadhyay, A.; Pal, R. Micro algal diversity of Kolkata, West Bengal, India. Indian Hydrobiol., v. 12, p. 204-224, 2010.

Comas González, A. Algunas características de la Flora de algas y cianoprocariotas de agua dulce de Cuba. ALGAS. Boletín de la Sociedad Española de Ficología, v. 39, p. 21-29, 2008.

Comas González, A.; Moreira González, A. Notas sobre algunas algas y cianoprocariotas dulceacuícolas de Cuba. ALGAS. Boletín de la Sociedad Española de Ficología, v. 43, p. 6-10, 2010.

Day, S. A.; Wickham, R. P.; Entwisle, T. J.; Tyler, P. A. Bibliographic check-list of nonmarine algae in Australia. Fl. Australia Suppl. Ser., v. 4, p. 1-276, 1995.

Deka, S. J.; Sarma, G. C. Taxonomical studies of Oscillatoriaceae (Cyanophyta) of Goalpara District, Assam, India. Indian J. Fundam. Appl. Life Sci., v. 1, p. 22-35, 2011.

Desikachary, T. V. Cyanophyta. New Delhi, India: ICAR, 1959.

Di Pippo, F.; Ellwood, N. T. W.; Guzzon, A.; Bohn, A.; Congestri, R. Diversity and biomass accumulation in cultured phototrophic biofilms. European J. Phycol., v. 49, p. 384-394, 2014.

Figueroa-Torres, M. G.; Arana-Magallón, F.; Almanza-Encarnación, S.; Ferrara-Guerrero, M. J., Ramos-Espinosa, M. G. Microalgas del Área Natural Protegida Ejidos de Xochimilco y San Gregorio Atlapulco, México. Ciencia UAT, v. 9, p. 15-29, 2015.

Geitler, L. Cyanophyceae in Rabenhorst's Kryptogamen-Flora. Leipzig, v. 14, p. 1-1196, 1932.
Gomont, M. Monographie des Oscillariées (Nostocacées homocystées). Ann. Sci. Nat. Bot. Ser., v. 15, p. 198-263, 1892.

Goyal, A.; Tyagi, S.; Tyagi, Y. Some Oscillatoria species from rice field soils of district Muzaffarnagar (U.P), India. Plant Arch., v. 8, p. 367-368, 2008.

Guiry, M. D.; Guiry, G. M. AlgaeBase. Worldwide electronic publication, National University of Ireland, Galway, 2016. Available from: $<$ http://www.algaebase.org $>$. Accessed on: Nov. 23, 2016.

Gupta, R. K. Algal Flora of Dehradun District Uttaranchal. Kolkata, India: Botanical Survey of India, Salt Lake, 2005.

Gupta, R. K.; Kumar, M; Paliwal, G. S. Glimpses of Cyanobacteria. India: New Delhi, Daya Publishing House, 2006.

Gupta, P. Algae of India. A Checklist of Cyanoprokaryota (Cyanophyceae). Salt Lake, Kolkata: Botanical Survey of India, 2012. v. 1.

Halder, N. New report of Anabaena Bory from Hooghly District in West Bengal, India. Int. J. Innovative Res. Rev., v. 3, p. 94-98, 2015 a.

Halder, N. Phytoconstituents composition and in vitro antibacterial activity of a blue green alga Anabaena variabilis Kütz. ex Born. et Flah. Tropical Plant Res., v. 2, p. 288-291, 2015 b.

Halder, N. Taxonomical studies of three species of an epiphytic alga Coleochaete Bréb. with ecological notes in West Bengal, India. Our Nat., v. 13, p. 19-25, 2015c.

Halder, N. Morpho-taxonomy of Hydrodictyon reticulatum (L.) Lagerheim and Pediastrum tetras var. tetraodon (Corda) Hansgirg, Hooghly, West Bengal, India. Tropical Plant Res., v. 2, p. 168-171, 2015d.

Halder, N. Recollections and taxo-ecological studies of Coleochaete scutata Bréb., Coleochaete pseudosoluta Gauthier-Lièvre and Coleochaete conchata Möb., West Bengal, India. Nepalese J. Biosci., v. 5, p. 21-25, 2015 e. Halder, N. Chemical composition and antibacterial activity of Lyngbya major Menegh. ex Gomont. Appl. Sci. Rep., v. 13, p. 25-28, 2016a.

Halder, N. On the occurrence of Johannesbaptisia pellucida (Dickie) W. R. Taylor et Drouet from freshwater habitat in West Bengal, India. Curr. Life Sci., v. 2, p. 7985, 2016b.

Halder, N. Taxonomy and periodicity of Chlorococcum Fries, Coelastrum Näg. and Scenedesmus Meyen in Hooghly, West Bengal, 
India. Mesop. Environ. J., v. 2, p. 47-56, 2016c.

Halder, N. Note on Ankistrodesmus Corda and Kirchneriella Schmidle in Hooghly, West Bengal, India. Mesop. Environ. J., v. 2, p. 40-46, $2016 \mathrm{~d}$.

Halder, N. Studies on the occurrence of three taxa of Zygnema C. Ag. from Hooghly, West Bengal, India. Malaya J. Biosci., v. 3, p. 8-14, 2016 e.

Halder, N.; Sinha, S. N. Diversity of the genera Gloeotrichia Agardh and Rivularia (Roth.) Agardh from Hooghly district of West Bengal, India. Indian J. Fundam. Appl. Life Sci., v. 3, p. 29-35, 2013a.

Halder, N.; Sinha, S. N. Some new records of the species of the genera Aphanothece Näg and Merismopedia Meyen from Hooghly district, West Bengal, India. Indian J. Plant Sci., v. 2, p. 58-65, 2013b.

Halder, N.; Sinha, S. N. Phytoconstituent analysis and antibacterial activity of Nitella flagelliformis A. Braun collected from a pond of Khamargachi of Hooghly District, West Bengal, India. Int. J. Pharm. Biol. Arch., v. 5, p. 6669, 2014a.

Halder, N.; Sinha, S. N. New records of Euglena acus (O.F. Müll.) Ehr. and Phacus acuminatus (A. Stokes) Huber-Pestalozzi of Euglenineae from Hooghly district, West Bengal. J. Acad. Ind. Res., v. 3, p. 333-336, 2014b.

Harris, T. D.; Smith, V. H.; Graham, J. L.; Van de Waal, D. B.; Tedesco, L. P.; Clercin, N. Combined effects of nitrogen to phosphorus and nitrate to ammonia ratios on cyanobacterial metabolite concentrations in eutrophic Midwestern USA reservoirs. Inland Waters, v. 6, p. 199-210, 2016.

Issa, A.; Abd-Alla, M.; Ohyama, T. Nitrogen fixing Cyanobacteria: Future prospect. In: Ohyama, T. (ed.). Advances in Biology and Ecology of Nitrogen Fixation. Intechopen, 2014. p. 23-48.

Jain, D. S. A systematic account of Oscillatoria species from Sonvad dam and Devbhane dam of Dhule, Maharashtra. J. Exp. Biol. Agric. Sci., v. 3, p. 132-137, 2015.

Kachroo, F. Aquatic vegetation of Damodar Vally. J. Asiatic Soc., v. 1, p. 271-298, 1959.

Kamat, N. D. The Oscillatoriaceae of Ahmedabad, India. J. Univ. Bombay, v. 31, p. 20-27, 1963.

Kasthuri, C.; Doss, A.; Rukshana, M. S. Studies on biodiversity of cyanobacteria in polluted ponds of Pattukkottai, Tamil Nadu, India. J. Algal Biomass Utln., v. 7, p. 58-64, 2016.

Kesarwani, S.; Tandon, R; Tiwari, G. L. The genus Oscillatoria Vaucher (Cyanoprokaryota) from India. Phykos, v. 45, p. 18-29, 2015.

Komárek, J.; Anagnostidis, K. Süßwasserflora von Mitteleuropa 19/2, Cyanoprokaryota. In Büdel, B.; Gärtner G.; Krientz, L.; Schagest, M. (ed.). 2. Teil/Part 2: Oscillatoriales. Spektrum Akademischer Verlag, 2005. p. 1-759.

Konopka, A.; Brock, T. D. Effect of temperature on blue-green algae (Cyanobacteria) in Lake Mendota. Appl. Environ. Microbiol., v. 36, p. 572-576, 1978.

Kullberg, R. G. The effect of some ecological factors on cell size of the hot spring alga Synechococcus lividus (Cyanophyta). J. Phycol., v. 13, p. 111-115, 1977.

Kumawat, D. A.; Jawale, A. K. The genus Oscillatoria Vaucher from fish ponds of Jalgaon district, Maharashtra (India). J. Ind. Bot. Soc., v. 85, p. 97-102, 2006.

Lashari, K. H.; Korai, A. L.; Sahato, G. A. Biodiversity of Oscillatoria (Nostophyceae, Cyanophyta) from lakes and ponds of Sindh. Res. J. Fish. Hydrobiol., v. 4, p. 73-85, 2009.

Mahajan, A. D.; Patel, R. J. Oscillatoria Vaucher (Cyanophyceae) from paddy fields of Kaira Districts, Gujarat, India. Indian Bot. Reptr., v. 8, p. 5-11, 1989.

Martens, G. V. A fifth list of Bengal algae (determined by Martens, G. V. Communicated by Kürz., S.). Proc. Asiatic Soc. Beng., v. 40, p. 170-173, 1871.

McGregor, G. B. Freshwater Cyanoprokaryota of North-Eastern Australia I: Oscillatoriales. Canberra: Australian Biological Resources Study, 2007.

Mur, L. R.; Skulberg, O. M.; Utkilen, H. Cyanobacteria in the environment. In: Chorus, I.; Bartram, J. (ed.). Toxic Cyanobacteria in water: a guide to their public health consequences, monitoring and management. London: E \& FN Spon., 1999. p. 15-40.

Naskar, N.; Naskar, K. R.; Sen, C. R. Backish water Oscillatoriaceae from North 24-Parganas, West Bengal, India. Bangladesh J. Plant Taxon., v. 15, p. 31-38, 2008.

Nassar, M. Z. A.; Khairy, H. M. Checklist of phytoplankton species in the Egyptian waters of the Red Sea and some surrounding habitats (1990-2010). Annual Res. Rev. Biol. v. 4, p. 3566-3585, 2014.

Nayak, S.; Prasanna, R. Soil pH and its role in cyanobacterial abundance and diversity in rice 
field soils. Appl. Ecol. Environ. Res., v. 5, p. 103-113, 2007.

Pal, U. C.; Santra, S. C. Algal flora of Midnapore, West Bengal (India). I. Cyanophyceae. Phykos, v. 24, p. 12-17, 1985.

Pal, U. C.; Santra, S. C. Some new additions of algal flora of West Bengal (India). I. Cyanophyceae. J. Indian Bot. Soc., v. 66, p. 365-369, 1987.

Patrick, R. Algae as indicator of pollution. In biological problems in water pollution. 3rd. Seminar Bot. A. Tuft. Sanitory Eng. Centre Cincinati Ohio, p. 223-232, 1965.

Pham, M. N.; Tan, H. T. W.; Mitrovic, S.; Yeo, H. H. T. A Checklist of the Algae of Singapore. Singpore: Raffles Museum of Biodiversity Res., National University of Singapore, 2011.

Prabakaran, M. In vitro antimicrobial potentials of marine Oscillatoria species. Asian J. Plant Sci. Res., v. 1, p. 58-64, 2011.

Prain, D. The vegetation of the district Hooghly, Howrah and 24-Parganas. Rec. Bot. Surv. India, v. 3, p. 143-339, 1905.

Prasad, B. N; Srivastava, M. N. Fresh Water Algal Flora of Andaman and Nicobar Islands Vol. I. India: Dehra Dun, Bishen Singh Mahendra Pal Singh, 1992.

Prescott, G. W. Algae of the Western Great Lakes Area. 2 ed. Dubuque, Iowa: W.M.C. Brown Co., 1962.

Rai, S. K.; Rai, R. K.; Jha, S. Cyanobacteria of Nepal: a checklist with distribution. Our Nat., v. 8, p. 336-354, 2010.

Robarts, R. S.; Zohary, T. Temperature effects on photosynthetic capacity, respiration and growth rates of bloom-forming cyanobacteria. New Zealand J. Mar. Freshwater Res., v. 21, p. 391-399, 1987.

Rodriguez, P. L.; Pizarro, H.; Maidana, N.; Dos Santos, A.; Bonaventura, S. M. Epixylic algae from a polluted low land river of Buenos Aires Province (Argentina). Cryptogam. Algol., v. 27, p. 63-83, 2006.

Roger, P. A.; Reddy, P. M. Characterization and classifications of blue-green algae/ Cyanobacteria. 2nd Semester on Biology of Blue-Green Algae and Their Symbiotic Forms. Pierre-Armand-Roger. fr., UPLB, Philippines, 1984. p. 1-15.

Santra, S. C.; Pal, U. C.; Maity, H.; Bandyopadhyay, G. Blue green algae in saline habitats of West Bengal, A systematic account. Biol. Mem., v. 14, p. 81-108, 1988.
Saravanan, M.; Elango, K.; Chandrashekaran, S.; Anand, N.; Nagaraja, V. A new type II restriction endonuclease, OfoI from nonheterocystous cyanobacterium Oscillatoria foreaui. Curr. Sci., v. 85, p. 188-191, 2003.

Seal, T.; Halder, N.; Chaudhuri, K.; Sinha, S. N. Evaluation of antioxidant activities of algae and effect of solvent extraction system. Int. J. Pharm. Sci. Res., v. 6, p. 1273-1278, 2015.

Sen Sarkar, N.; Bandyopadhyaya, T.; Dutta, S.; Das, S. Algae in the Assessment of Industrial Effluents: Case Study in Southern Bengal, India. J. Environ. Pathol. Toxicol. Oncol., v. 32, p. 101-114, 2013.

Sen, C. R.; Gupta, D. The genus Oscillatoria Vaucher from greater Calcutta. Bull. Bot. Soc. Beng., v. 41, p. 41-45, 1987.

Sen, C. R.; Gupta, D. The genus Oscillatoria vaucher from lower Gangetic plains of West Bengal. Phykos, v. 37, p. 89-93, 1998.

Sen, N.; Naskar, K. Algal Flora of Sundarban Mangals. New Delhi, India: Daya Publishing House, 2003.

Sikdar, J.; Keshri, J. P. The genus Oscillatoria Vaucher (Oscillatoriales: Cyanoprokaryota) in West Bengal, India. Int. J. Cur. Res. Rev., v. 6, p. 47-59, 2015.

Silva, P. C.; Basson, P. W.; Moe, R. L. Catalogue of the benthic marine algae of the Indian Ocean. Univ. California Publ. Bot., v. 79, p. 1-1259, 1996.

Sinha, S. N.; Halder, N. New report Of Dichotomosiphon Tuberosus (A.Br.) Ernst and Vaucheria Sessilis D.C. of the family Vaucheriaceae from Hooghly district, West Bengal, India. Ecoprint, v. 21, p. 49-53, 2014.

Sinha, J. P.; Mukherjee, D. On blue-green algae from the paddy fields of Bankura district of West Bengal-I. Phykos, v. 14, p. 117-118, 1975.

Sinha, S. N.; Paul, D.; Halder, N.; Sengupta, D.; Patra, S. K. Green synthesis of silver nanoparticles using fresh water green alga Pithophora oedogonia (Mont.) Wittsock and evaluation of their antibacterial activity. Appl. Nanosci., v. 5, No. 6, p. 703-709, 2015. https://dx.doi.org/10.1007/s13204-014-0366-6

Smith, T. E. Revised list of algae from Arkansas, U.S.A. and new additions. Int. J. Alg., v. 12, p. 230-256, 2010.

Smith, V. H. Low nitrogen to phosphorus ratios favors dominance by blue-green algae in lake phytoplankton. Science, v. 221, No. 4611, p. 669-671, 1983. https://doi.org/10.1126/science.221.4611.669 
Täuscher, L. Untersuchungen der Mikroalgen in Moorgewässern des Naturparks 'Uckermärkische See' im Land Brandenburg. Essen: Deutsche Gesellschaft für Limnologie (DGL). Erweiterte Zusammenfassungen der Jahrestagung, 2015. $<$ http://www.dglev.de/cms/upload/dokumente/Erweiterte_Zusam menfassungen_Essen_2015.pdf $>$. Accessed on: Nov. 23, 2016.

Tell, G. Catálogo de las algas de agua dulce de la República Argentina. Biblioth. Phycol. J. Cramer in der A. R. Gantner Verlag Kommanditgesellschaft, Band 70, p. 1-283, 1985.

Tiwari, G. L. A study of blue-green algae from paddy field soils of India. Taxonomic consideration of non-heterocystous blue-green algae. Nova Hedw., v. 26, p. 765-798, 1975.

Tiwari, G. L.; Kant, R.; Tiwari, O. N.; Tandon, R.; Kushwaha, L. L. Distribution, diversity and characterization of cyanobacteria of rice fields. Proc. Nat. Acad. Sci. India, v. 77, p. 387-402, 2007.

Verma, J.; Mohanty, R. C. Phytoplankton and its correlation with certain physiochemical parameters of Danmukundpur pond. Poll. Res., v. 14, p. 233-242, 1995.

Whittaker, R. H. New concepts of kingdoms of organisms. Science, v. 163, No. 3863, p. 150160, 1969. https://dx.doi.org/10.1126/science.163.3863.150 Whitton, B. A.; John, D. M.; Kelly, M. G.; Haworth, E. Y. A Coded List of Freshwater Algae of the British Isles. 2 ed. World-wide Web electronic publ., 2003. Available from: $<$ http://www.nhm.ac.uk/our-science/data/ukspecies/checklists/NHMSYS0000591449/index. html>. Accessed on: Nov. 23, 2016.

License information: This is an open-access article distributed under the terms of the Creative Commons Attribution License, which permits unrestricted use, distribution, and reproduction in any medium, provided the original work is properly cited.

Braz. J. Biol. Sci., 2017, v. 4, No. 7, p. 89-101. 